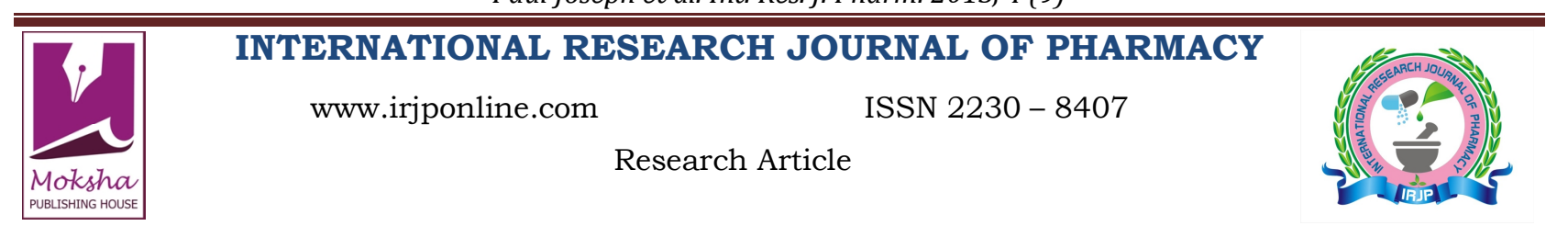

\title{
COMPARATIVE EVALUATION OF THE BONDING EFFICACY OF SIXTH, SEVENTH AND EIGHTH GENERATION BONDING AGENTS: AN IN VITRO STUDY
}

Paul Joseph ${ }^{1}$, Chakravarthy Yadav ${ }^{1}$, Kumar Satheesh ${ }^{1}$, Raju Rahna ${ }^{2}$

${ }^{1}$ Department of Conservative Dentistry and Endodontics, Vinayaka Mission Dental College, Salem, Tamil Nadu, India

${ }^{2}$ Former PG student, Department of Conservative Dentistry and Endodontics, Vinayaka Mission Dental College, Salem, Tamil Nadu, India

*Corresponding Author Email: rahna_jerin@yahoo.com

Article Received on: 17/08/13 Revised on: 07/09/13 Approved for publication: 18/09/13

DOI: $10.7897 / 2230-8407.04930$

IRJP is an official publication of Moksha Publishing House. Website: www.mokshaph.com

(C) All rights reserved.

\section{ABSTRACT}

The aim of the study was to compare In-vitro the micro tensile bond strength of sixth generation (Clearfil SE Bond, Kuraray, Japan), seventh generation (Adper Easy One, 3 M ESPE, Germany) and eighth generation ((Futurabond DC, Voco, Germany) dentin bonding agents. Twenty freshly extracted caries free, unrestored human molars were selected. The occlusal surfaces were ground flat; divided into four groups of five each according to the bonding agent applied and covered with composite resin (10 mm in height). The teeth were sectioned into one mm thick specimens with a cross sectional area of $1 \mathrm{~mm}$ square in hard tissue microtome and subjected to tensile force in a universal testing machine. The highest strength was seen in $8^{\text {th }}$ generation bonding agent (Futura bond DC, Voco, Germany) $34.9332 \mathrm{MPa}$ followed by $6^{\text {th }}$ generation bonding agent $32.3477 \mathrm{MPa}$ (Clearfil SE Bond, Kuraray dental, Japan) and the $7^{\text {th }}$ generation agent 31.8826 MPa (Adper Easy One, 3M ESPE, Germany) respectively. The eighth generation dentin bonding agent appeared to be more advantageous in bonding than sixth and seventh generation dentin bonding agents.

Keywords: Research, micro tensile bond strength, sixth, seventh and eighth generation bonding agents.

\section{INTRODUCTION}

The classic concepts of operative dentistry have been challenged by contemporary restorative techniques based on the adhesive properties of tooth colored restorative materials. The scientific beginnings of dental adhesion originated in the early 1950's and now bonding agents are used routinely in restorative and preventive dentistry. ${ }^{1}$ Dentin bonding agent can be defined as a thin layer of resin applied between the conditioned dentin and resin matrix of a composite. ${ }^{2}$ Over the years there have been numerous classifications of dentin bonding agents that have been advocated by many authorities. Some of the commonly followed classifications include that; based on generations (e.g. First generation dentin bonding agents, second generation dentin bonding agents, third generation dentin bonding agents etc,); a scientific classification based on treatment of smear layer and number of clinical steps; classification based on modern adhesion strategy as total etch or self etch. ${ }^{3,4}$ The total-etch technique, initiated by Fusayama advocated etching both enamel and dentin simultaneously using phosphoric acid before the application of a phosphate ester type of bonding agent. Total etch adhesives can be two step adhesives or three step adhesives. ${ }^{5}$ The concept of self- etch primers was introduced with Scotch bond 2 in the early 90's. However this system required a selective enamel etching step. The current self etch adhesives provide monomer formulations for simultaneous conditioning and priming of both enamel and dentin. Self etch adhesives are subdivided depending on their $\mathrm{pH}$ and etching potential as mild, moderate and intermediary strong self etch adhesives. ${ }^{6,7}$ Presently the sixth and seventh generation dentin bonding agents belong to the self-etch strategy. Nano dentistry with its technologically advanced clinical tools and devices has influenced every field of dentistry including restorative dentistry. Nano composites and nano adhesives are one of the greatest contributions of nano dentistry which contain nanosized fillers. Nano adhesives are solutions with nano particles which prevent agglomeration thus producing high dentin and enamel bond strength, high stress absorption, longer shelf life, durable marginal seal and the release of fluorides. ${ }^{8,9}$ Although most bonding agents are unfilled, some products contain inorganic fillers ranging from $0.5 \%$ to $40 \%$ by weight. Filler particles include micro fillers, also called nano fillers and sub-micron glass. Filled bondings agents tend to produce higher in vitro bond strength. ${ }^{6}$ Recently dentin adhesives that contain nano fillers have been introduced. The manufacturers of one such system of nano filler containing dentin bonding agent (Futurabond DC, Voco, Germany) have claimed them to be the eighth generation. The purpose of this study was to compare In-vitro the micro tensile bond strength of three different self etching adhesives; a sixth generation dentin bonding agent (Clearfil SE Bond, Kuraray, Japan), seventh generation dentin bonding agent (Adper Easy One, $3 \mathrm{M}$ ESPE, Germany) with that of the nano filler containing eighth generation dentin bonding agent (Futurabond DC, Voco, Germany).

\section{MATERIALS AND METHODS}

A total of twenty freshly extracted caries free, unrestored human molars were selected and stored in distilled water. The teeth were divided into four groups of five each according to the bonding agent applied.

Group 1 Control group (without any bonding agent)

Group 2 Bonded using the sixth generation bonding agent, Clearfil SE bond (Kuraray)

Group 3 Bonded using seventh generation bonding agent, Adper Easy One (3M ESPE)

Group 4 Bonded using eighth generation bonding agent, Futurabond DC (Voco America)

The occlusal surfaces of these teeth were ground using a water cooled diamond disc mounted on an air motor hand piece until all occlusal enamel was removed. The entire flat surfaces were covered with composite resin following 
application of bonding agents. The adhesives were applied according to the manufacturer's instructions and cured via Light Emitting Diode (3M ESPE) unit set at 1000 milli Watt $/ \mathrm{cm}^{2}$. Resin composite build-ups (Filtek Z350, 3M ESPE, St. Paul, Minn, USA) were constructed on the bonded surfaces in $1.5 \mathrm{~mm}$ increments; each was light cured for 20 seconds with the same light unit at a distance of $2 \mathrm{~mm}$ (Figure 1). The teeth were individually embedded in acrylic resin blocks. The blocks were mounted in hard tissue microtome and sectioned into one $\mathrm{mm}$ thick specimens (Figure 2). The resulting specimen was rotated another ninety degree and serial sectioning continued. The resulting specimens had a cross sectional area of $1 \mathrm{~mm}$ square (Figure 3 ). The cross-sectional area of each stick/specimen was measured individually with a digital caliper. The sectioned teeth were divided into four experimental groups with twenty specimens in each group according to bonding agent applied. All the specimens were stored in distilled water for 24 hours prior to micro tensile bond strength testing. Micro tensile bond strength testing was done using a universal testing machine (KIC-2-050-C, Kalpak Instruments and Controls) which was available at Department of Mechanical Engineering, IIT Chennai (Figure 4). The specimens were attached to a modified device (Custom made jig for micro tensile testing) and subjected to a tensile force in a Universal Testing Machine at a crosshead speed of $0.5 \mathrm{~mm} /$ minute. Bond strength values were calculated in $\mathrm{MPa}$, where the applied force $(\mathrm{N})$ was divided by the stick cross-sectional area $\left(\mathrm{mm}^{2}\right)$ Universal testing machine is a very precise machine used for subjecting small size specimens for various tests. The failure load was observed on the display panel attached to the universal testing machine. Tensile force required to debond the specimen, was recorded. Debonding stress in Megapascal was then calculated by the ratio of maximum load in Newton to the surface area of the prepared specimen $\left(\mathrm{Mpa}=\mathrm{N} / \mathrm{mm}^{2}\right)$. The data so obtained were tabulated and analyzed statistically.

\section{RESULTS}

The mean micro tensile bond strength and standard deviation were calculated for each group and are summarized in the Table 1. The mean micro tensile bond strength value for sixth generation adhesive was $32.3477 \mathrm{Mpa}$, seventh generation adhesive was $31.8826 \mathrm{Mpa}$ and eighth generation adhesive was $34.9332 \mathrm{Mpa}$ respectively. The highest strength was seen in $8^{\text {th }}$ generation bonding agent (Futura bond DC, Voco, Germany) followed by $6^{\text {th }}$ generation bonding agent (Clearfil SE Bond ,Kuraray dental, Japan) and the $7^{\text {th }}$ generation agent (Adper Easy One, 3M ESPE, Germany). ANOVA Test was performed to determine any statistically significant differences among the groups compared in this study. The Analysis of variance test compared the mean scores of four groups. In this analysis the difference between the mean micro tensile bond strength values of Group 1, Group 2, Group 3 and Group 4 were compared. The results of comparison of all the four groups are shown in Table 2. The analysis of variance showed that there was statistically significant difference in micro tensile bond strengths between the four groups. The highest strength was seen in eighth generation bonding agent (Futurabond DC, Voco, Germany) followed by sixth (Clearfil SE Bond, Kuraray Dental, Japan) and the seventh generation (Adper Easy One, 3MESPE, Germany) respectively. To identify which sub group (control versus $6^{\text {th }}, 7^{\text {th }}$ and $8^{\text {th }}$ generation; $6^{\text {th }}$ generation versus $7^{\text {th }}$ and $8^{\text {th }}$ generation; $7^{\text {th }}$ generation versus, $8^{\text {th }}$ generation) was showing the difference Post Hoc Tukey's Test was done. The results are given in Table 3. The result showed that the eighth generation bonding agent( Futurabond DC, Voco, Germany) showed highest bond strength followed by sixth generation bonding agent (Clearfil SE bond, Kuraray Dental, Japan) and seventh generation bonding agent (Adper Easy One, 3M ESPE, Germany) respectively. The results are summarized in Graph1.

\section{DISCUSSION}

The objective of bond strength test is to establish a demonstrative value for how strong the bonding of an adhesive system is to the dental hard tissues. Polymerization shrinkage is still a major problem when composites are bonded to tooth. Polymerization shrinkage is induced during the conversion of monomer molecules into a polymer network. During this process Vander Waals and hydrogen interactions are replaced with shorter covalent bonds. This creates contraction stress which initiates the failure of the composite-tooth interface if the forces of polymerization contraction exceed dentin bond strength. If this occurs, adverse consequences such as postoperative sensitivity, micro leakage, secondary caries and micro cracking of the restorative material can occur. An estimated bond strength of $17-21 \mathrm{MPa}$ has been proposed as the critical value needed to withstand these stress of polymerization contraction of the composite material. ${ }^{11,12}$ Several factors influence in-vitro bond strength to dentin such as the type and age of the teeth, the degree of dentin mineralization, the dentin surface being bonded, the type of bond strength test (shear or tensile), the storage media, environmental relative humidity in substrates, complex nature of the testing procedures, sensitivity of manipulation of these systems and the composite restorative material. ${ }^{13}$ All the four dentin bonding agents tested in this study were self etching bonding agents. Self etch approach can in general be classified into a two step or one step application procedure. Self-etch adhesives differ in their aggressiveness. Therefore they are classified in three categories according to acidity: mild, moderate and aggressive. Since the self-etch adhesives are not as aggressive as the phosphoric acid gel in etch-and-rinse adhesives, most do not remove the smear layer. ${ }^{4}$ Strong self etch adhesives cause complete dissolution of nearly all hydroxyapatite crystals. The underlying bonding mechanism is primarily diffusion based and have been often documented with rather low bond strength values. Mild self etch systems, in general have a $\mathrm{pH}$ of around 2 and demineralise dentin only to depth of one micro meter. The superficial demineralization partially keeps the residual hydroxyapatite still attached to collagen. ${ }^{14-}$ ${ }^{16}$ The $\mathrm{pH}$ of the bonding agents used in this study varied and was 1.9 for the sixth generation dentin bonding agent (Clearfil SE Bond, Kuraray Dental, Japan), 2.3 for the seventh generation bonding agent (Adper Easy One, 3M ESPE, Germany) and 2.0 for the eighth generation bonding agent (Futurabond DC, Voco, Germany). The $\mathrm{pH}$ of all the adhesives used comes around the range of two and belonged to the mild self etch category. However difference in bond strengths was shown between these adhesives. The recently introduced eighth generation dentin bonding agent (Futurabond DC, Voco, Germany) contains significant amounts of highly functional nano sized cross linking agents, the silica particles and has the advantage of being dual cured. 
Paul Joseph et al. Int. Res. J. Pharm. 2013, 4 (9)

Table 1: Comparison of mean micro tensile bond strength and standard deviation of control, sixth generation, seventh generation and eighth bonding agents

\begin{tabular}{|c|c|c|c|c|}
\hline \multirow{2}{*}{ Group } & \multicolumn{2}{|c|}{ Range } & \multirow{2}{*}{ Mean } & \multirow{2}{*}{ SD } \\
\cline { 2 - 3 } & Min & Max & & \\
\hline Control & 2.103 & 5.124 & 3.1000 & 0.91191 \\
\hline Sixth Generation (Clearfil SE Bond) & 30.124 & 35.510 & 32.3477 & 1.57502 \\
\hline Seventh Generation (Adler Easy One) & 28.786 & 35.784 & 31.8826 & 2.14201 \\
\hline Eighth Generation (Futurabond DC) & 30.122 & 38.541 & 34.9332 & 2.53679 \\
\hline
\end{tabular}

Table 2: Comparison of micro tensile bond strength of all four groups using ANOVA test

\begin{tabular}{|c|c|c|c|c|c|c|}
\hline \multicolumn{9}{|c|}{ Micro tensile Strength } & F & Sig. \\
\hline & N & Mean & Std. Deviation & Mean Square & F & \\
\hline CONTROL & 20 & 3.1000 & 0.91191 & 4522.368 & 1261.842 & $<0.001$ \\
\hline $\begin{array}{c}6^{\text {th }} \text { Generation bonding agent (CLEARFIL } \\
\text { SE BOND) }\end{array}$ & 20 & 32.3477 & 1.57502 & & \\
\hline $\begin{array}{c}7^{\text {th }} \text { Generation bonding agent (ADPER } \\
\text { EASY ONE) }\end{array}$ & 20 & 31.8826 & 2.14201 & & & \\
\hline $\begin{array}{c}8^{\text {th }} \text { Generation bonding agent (FUTURA } \\
\text { BOND DC) }\end{array}$ & 20 & 34.9332 & 2.53679 & & \\
\hline Total & 80 & 25.5659 & 13.23568 & & \\
\hline
\end{tabular}

(N - Sample Size, F - Value of the test, Sig - Significance)

Table 3: Multiple Comparison using Post Hoc Tukey's Test

\begin{tabular}{|c|c|c|c|c|}
\hline \multicolumn{5}{|c|}{\begin{tabular}{|c|} 
Multiple Comparisons \\
\end{tabular}} \\
\hline \multicolumn{5}{|c|}{ Dependent Variable: Micro tensile Strength, Tukey HSD } \\
\hline (I) Groups & (J) Groups & Mean Difference (I-J) & Std. Error & Sig. \\
\hline \multirow[t]{3}{*}{ Control } & $\begin{array}{c}6^{\text {th }} \text { generation bonding } \\
\text { agent.(Clearfil SE Bond })\end{array}$ & -29.24770 & 0.59866 & $<0.001$ \\
\hline & $\begin{array}{l}7^{\text {th }} \text { generation bonding agent } \\
\text { (Adper Easy One). }\end{array}$ & -28.78258 & 0.59866 & $<0.001$ \\
\hline & $\begin{array}{c}8^{\text {th }} \text { generation bonding agent } \\
\text { (Futurabond DC) }\end{array}$ & -31.83315 & 0.59866 & $<0.001$ \\
\hline \multirow[t]{2}{*}{$\begin{array}{l}6^{\text {th }} \text { generation } \\
\text { bonding agent }\end{array}$} & $\begin{array}{l}7^{\text {th }} \text { generation bonding agent } \\
\text { (Adper Easy One). }\end{array}$ & 0.46513 & 0.59866 & 0.865 \\
\hline & $\begin{array}{c}8^{\text {th }} \text { generation bonding agent } \\
\text { (Futurabond DC) }\end{array}$ & -2.58545 & 0.59866 & $<0.001$ \\
\hline $\begin{array}{l}7^{\text {th }} \text { generation } \\
\text { bonding agent }\end{array}$ & $\begin{array}{c}8^{\text {th }} \text { generation bonding agent } \\
\text { (Futurabond DC). }\end{array}$ & -3.05057 & 0.59866 & $<0.001$ \\
\hline
\end{tabular}

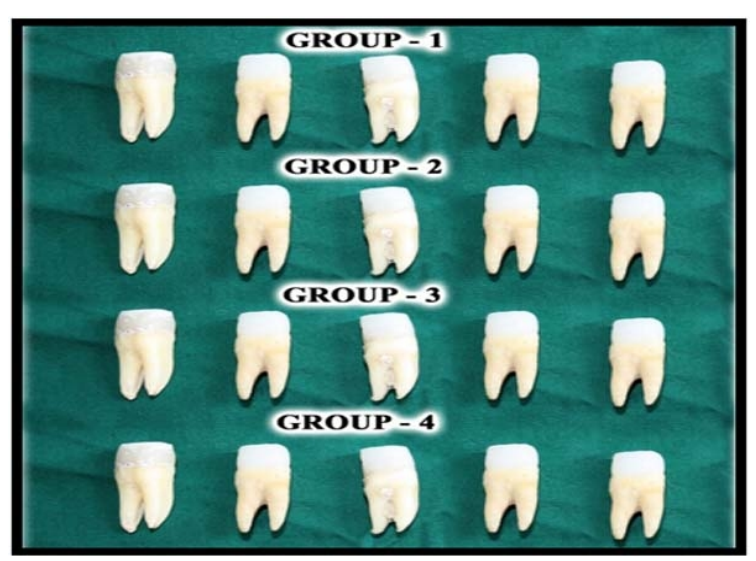

Figure 1: Composite bonded to tooth samples after application of different bonding agents

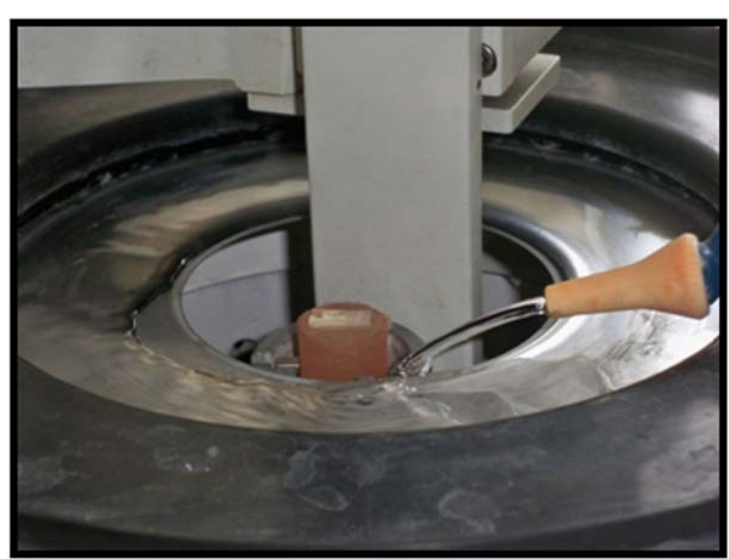

Figure 2: Sample mounted in the hard tissue microtome for sectioning 


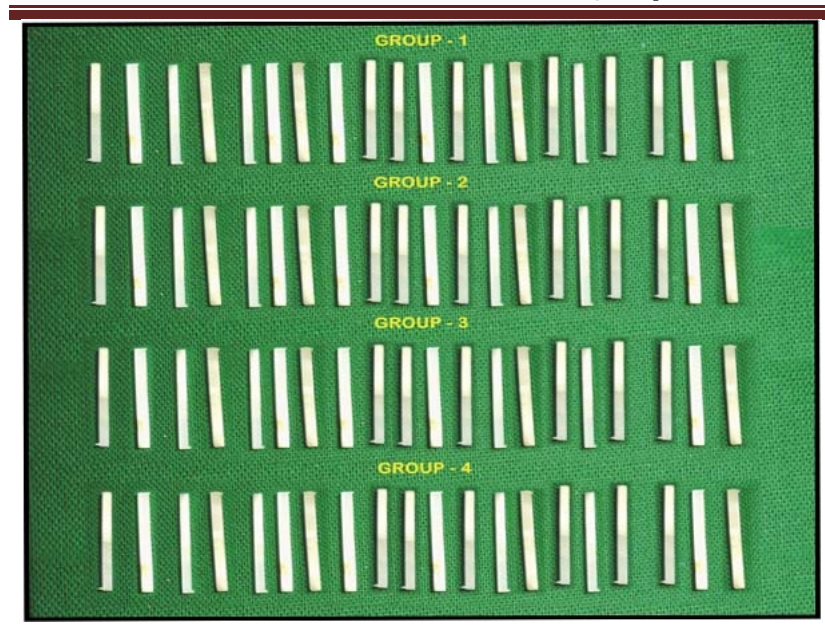

Figure 3: Specimens obtained after hard tissue microtome sectioning

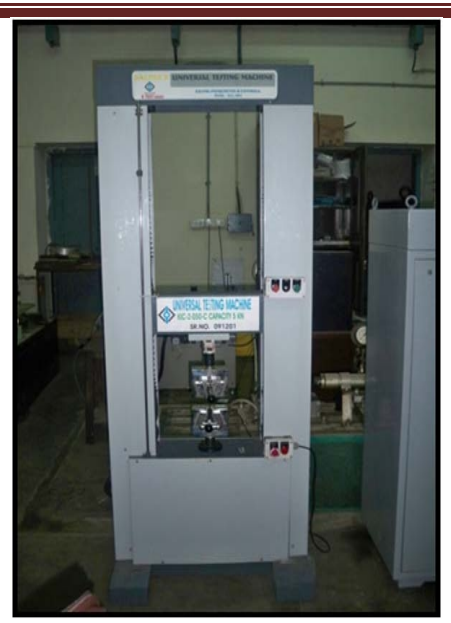

Figure 4: Universal Testing Machine

\section{MICROTENSILE STRENGTH}

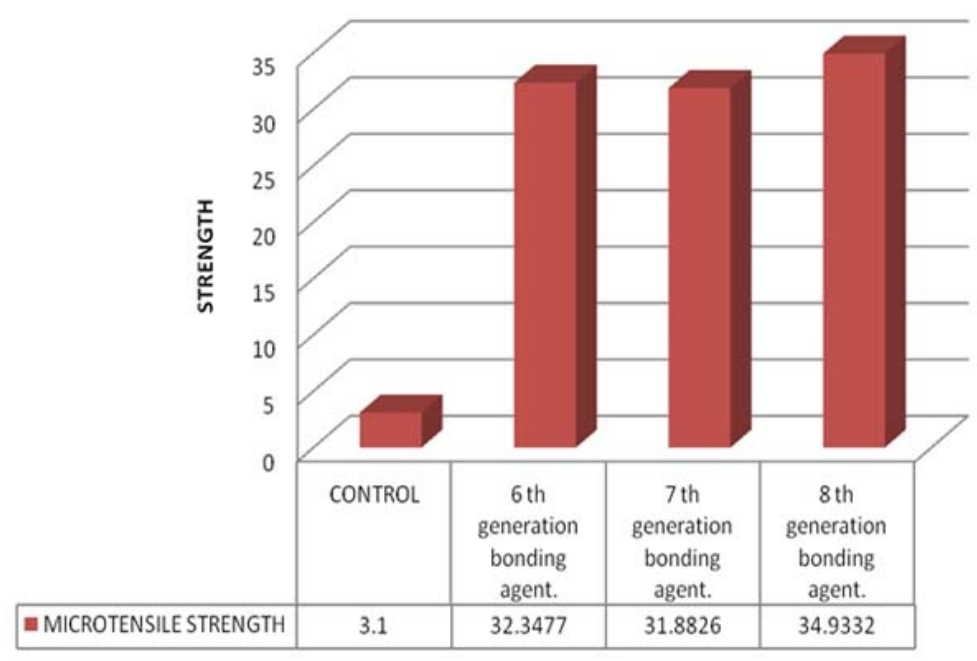

Graph 1: Comparative evaluation of micro tensile bond strengths of sixth, seventh and eighth generation bonding agents

In this study the highest mean micro tensile bond strength (34.9332 MPa) exhibited by the eighth generation bonding agent (Futurabond DC, Voco, Germany) group may be attributed to this nano sized cross linking agents as claimed by the manufacturer. In the present study, the mean value showed by the sixth generation dentin bonding agent (Clearfil SE Bond, Kuraray Dental, Japan) was $32.3477 \mathrm{MPa}$ and by the seventh generation dentin bonding agent (Adper Easy One) was $31.8827 \mathrm{MPa}$ respectively which are almost in agreement with recent studies. In this case the two step self etch adhesive, Clearfil SE Bond showed slightly higher bond strength than Adper Easy One, the one step self adhesive. This may be due to the component 10-MDP (10methacryloxydecyl dihydrogen phosphate) in the Clearfil SE Bond, which has the potential to bond chemically with the hydroxyapatite crystal. ${ }^{17}$ In addition the one step self-etch adhesive systems generally have less cross-linking monomers. These cross-linking monomers provide most of the mechanical strength, therefore there is a potential for lower bond strength as shown by seventh generation bonding agent, Adper Easy One (3M ESPE, Germany). Other variables like functional monomers, cross-linking monomers, solvents, inhibitors and activators may also differ in proportions and can affect bond strength. In brief, the amount of monomers, diluents and filler loads differs between products according to manufacturer's technology which is not well described in adhesive composition. Also little is known about the shrinkage and stiffness of these filled adhesives after polymerization. These factors could affect the micro tensile bond strength significantly but is not listed by manufacturer as the final formulation is proprietary secret. Errors in application technique, operator variability and inadequate primer drying time can also affect the bond strength of self etch adhesives specially water based system. ${ }^{18}$ It can be concluded within the limitations of this study conducted and results obtained that eighth generation (Futurabond DC, Voco, Germany) dentin bonding agents showed higher mean micro tensile bond strength (34.9332 $\mathrm{MPa}$ ) than sixth generation dentin bonding agent (Clearfil SE Bond, Kuraray Dental, Japan) and seventh generation dentin bonding agent (Adper Easy One ,3M ESPE,Germany).

\section{CONCLUSION}

Based on the results it was evaluated that eighth generation dentin bonding agent (Futurabond DC, Voco, Germany) performed the best in micro tensile bond strength to tooth than sixth generation dentin bonding agent (Clearfil SE 
Bond, Kuraray Dental, Japan) and seventh generation dentin bonding agent (Adper Easy One, 3M ESPE, Germany).

\section{REFERENCES}

1. Buonocore MG. A simple method of increasing the adhesion of acrylic filing materials to enamel surfaces. J Dent Res 1955; 34: 849-53. http://dx.doi.org/10.1177/00220345550340060801 PMid:13271655

2. Anusavice KJ, Santos JD, Shen C, Phillips RW. Phillips science of dental materials. $11^{\text {th }}$ ed. St. Louis (MO): Saunders; 2003.

3. Kugel Geroard, Ferrari Marco. The science of bonding from first to sixth generation. J Am Dent Assoc 2000; 131 Suppl: 20S-25S.

4. Jorge Perdigao. New developments in dental adhesion. Dent Clin North Am 2007; 51(2): 333-57. http://dx.doi.org/10.1016/j.cden.2007.01.001 PMid:17532916

5. Van Meerbeek B, Yoshihara K, Yoshida Y, Mine A, De Monck J, Van Panduit KL. State of the art of self-etch adhesives. Dent Mater 2011; 27(1): 17-28. http://dx.doi.org/10.1016/j.dental.2010.10.023 PMid:21109301

6. Pashley DH, Tay FR. Aggressiveness of contemporary self-etching adhesives. Part II: Etching effects on un-ground enamel. Dent Mater 2001; 17(5): 430-44. http://dx.doi.org/10.1016/S01095641(00)00104-4

7. Tay FR, Pashley DH. Aggressiveness of contemporary self-etching systems. Part I: Depth of penetration beyond smear layers. Dent Mater 2001; 17(4): 296-308. http://dx.doi.org/10.1016/S01095641(00)00087-7

8. Jhaveri HM, Balaji PR. Nano technolology: The future of dentistry. J Indian Prosthodont Soc 2005; 5: 15-17. http://dx.doi.org/10.4103/09724052.16335

9. Mitra SB, Wu D, Holmes BN. An application of nanotechnology in advanced dental materials. J Am Dent Assoc 2003; 134(10): 1382-90. PMid: 14620019

10. John M Powers, Robert G Craig. Craig's Restorative Dental Materials. $11^{\text {th }}$ edition. Mosby, St. Louis; 2002.
11. Davidson CL, De Gee AJ, Feilzer A. The competition between the composite-dentin bond strength and the polymerization contraction stress. J Dent Res 1984; 63(12): 1396-9. http://dx.doi.org/10.1177 /00220345840630121101 PMid:6239886

12. Munksgaard EC, Irie M, Asmussen E. Dentin-polymer bond promoted by Gluma and various resins. J Dent Res 1985; 64(12): 1409-11. http://dx.doi.org/10.1177/00220345850640121801 PMid:2934449

13. Diaz Arnold AM, Williams VD, Acquilino SA. A review of dentinal bonding in-vitro-the substrate. Oper Dent 1990; 15(2): 71-5. PMid:2197607

14. Shirai K, De Munck J, Yoshida Y, Inoue S, Lambrechts P, Suzuki K et al. Effect of cavity configuration and aging on the bonding effectiveness of six adhesives to dentin. Dent Mater 2005; 21(2): 110-24. http://dx.doi.org/10.1016/j.dental.2004.01.003 PMid:15681009

15. De Munck J, Shirai K, Yoshida Y, Inoue S, Van Landuyt K, Lambrechts $\mathrm{P}$, et al. Effect of water storage on the bonding effectiveness of six adhesives to Class I cavity dentin. Oper Dent 2006; 31(4): 456-65. http://dx.doi.org/10.2341/05-57 PMid:16924986

16. Brackett WW, Covey DA, St Germain Jr HA. One-year clinical performance of a self-etching adhesive in class $\mathrm{V}$ resin composites cured by two methods. Oper Dent 2002; 27(3): 218-22. PMid:12025819

17. Yoshida Y, Nagakane K, Fukuda R, Nakayama Y, Okazaki M, Shintani $\mathrm{H}$, et al. Comparative study on adhesive performance of functional monomers. J Dent Res 2004; 83(6): 454-8. http://dx.doi.org/10.1177/ 154405910408300604 PMid:15153451

18. Duke ES, Lindemuth J. Variability of clinical dentin substrates. Am J Dent 1991; 4(5): 241-6. PMid: 1810335

Cite this article as:

Paul Joseph, Chakravarthy Yadav, Kumar Satheesh, Raju Rahna. Comparative evaluation of the bonding efficacy of sixth, seventh and eighth generation bonding agents: An in vitro study. Int. Res. J. Pharm. 2013; 4(9):143-147 http://dx.doi.org/10.7897/2230-8407.04930 